\title{
Increasing Efficiency of Breeding Dairy Cattle in Agricultural Organizations of the Russian Federation
}

\author{
Anatoliy Timofeevich Stadnik ${ }^{1}$, Sergey Aleksandrovich Shelkovnikov ${ }^{1}$, Yvgeniy Vladimirovich Rudoy ${ }^{1}$, Danil \\ Maksimovich Matveev ${ }^{1} \&$ Gabdrahmanov Marat Maniehovich ${ }^{1}$ \\ ${ }^{1}$ Novosibirsk State Agrarian University, Russian Federation \\ Correspondence: Anatoliy Timofeevich Stadnik, Dobrolyubova Street, 160, Novosibirsk, 630039, Russian \\ Federation.
}

Received: November 17, 2014

Accepted: December 5, 2014 Online Published: March 20, 2015

doi:10.5539/ass.v11n8p201

URL: http://dx.doi.org/10.5539/ass.v11n8p201

\begin{abstract}
This work examines the current state of dairy cattle breeding in Russia and in the Siberian Federal District, on the example of the Novosibirsk region. Main disadvantages of the existing mechanism of state support for agriculture are defined. The authors propose a set of economic indicators that help to improve efficiency in allocating state funding on the basis of production volumes and the level of production costs in a separate agricultural organization, municipality, natural and economic zone and the region as a whole.
\end{abstract}

Keywords: agriculture, government regulation, dairy cattle, efficiency

\section{Introduction}

During the last decade, the Ministry of Agriculture has been paying increased attention to development of breeding dairy cattle industry, which significantly degraded in the period of reforming economy. Active implementation of target-oriented federal and departmental programs, in conjunction with annual growth in the amount of state support since 2005 have significantly reduced the rate of cattle stock decreasing, and in some sub-federal regions, a positive trend in the volume of industry gross domestic product is observed. 2009 saw the beginning of the construction of modern cattle breeding complexes based on the use of resource-saving technologies of stock keeping, whose product is commercially viable not only within the country but also in the international market.

However, in the regions of the Siberian Federal District, reduction in dairy livestock is observed. In 2012, as compared to 2000 , the number of cows in all categories of farms decreased by $42 \%$, including that in agricultural organizations - by $33 \%$. The produced milk is only enough to satisfy $78 \%$ of people's demand based on the norms established by the Institute of Nutrition of RAS. The main reasons for the current situation in these regions are harsh climatic conditions for keeping animals and for formation of forage reserve in farms, which leads to reduction in productivity and higher production costs as opposed to sub-federal regions located in the southern areas.

In modern conditions, development of new theoretical approaches and practical recommendations for the development of milk production in agricultural organizations on the basis of optimizing their production parameters, diversification, introduction of innovative technologies, government support has become vital.

A significant contribution to the study of current state and issues of state regulation in agriculture, particularly in dairy cattle breeding, was made by eminent scholars such as Cungu A., Gow H., Swinnen J. F. M., Vranken L., Von Witzke H., Polukhin A. A., Malyshkov V. I., Kovalev L. I., Kovalev I. L., Budanov I. A. Their works provided scientific basis for research study in strategic directions of market players development (Cungu et al., 2008; Von Witzke, 2008; Polukhin, 2014; Malyshkov, 2013; Kovalev \& Kovalev, 2013; Budanov, 2013).

\section{Main Part}

The Siberian Federal District includes 12 sub-federal regions of the Russian Federation ( 4 republics, 3 provinces, 5 regions) located in various climatic zones with specific landscapes. This affects specialization of production in livestock breeding and its development in whole. A typical representative with developed agricultural sector of economy in this region is the Novosibirsk region. The rates of livestock development here are close to the average values for the District (Official website of the Federal State Statistics Service). 
When comparing rate of the dairy cattle breeding development in the Novosibirsk region and in Russia as a whole, it was revealed that lack of differentiation in distribution of the state support during implementation of federal programs of agriculture development did not contribute to uniform development of the industry. This situation has led to a reduction in the number of cattle and dairy cattle population by almost $30 \%$ in the Novosibirsk region alone. With that, the growth in productivity allowed to prevent a decrease in gross milk production, both in the region and the country as a whole (Table 1).

Table 1. Dynamics of livestock population and productivity

\begin{tabular}{llllllll}
\hline Indicator & 2005 & 2009 & 2010 & 2011 & 2012 & 2013 & 2013 in \% to 2005 \\
\hline Cattle, thous. animals & & & & & & & \\
Russian Federation & 21,625 & 20,671 & 19,968 & 20,111 & 19,930 & 19,564 & 90.5 \\
$\begin{array}{l}\text { Novosibirsk region } \\
\text { Cows population, thous. animals }\end{array}$ & 699 & 565 & 551 & 553 & 522 & 491 & 70.3 \\
$\begin{array}{l}\text { Russian Federation } \\
\text { Povosibirsk region }\end{array}$ & 282 & 9,026 & 8,844 & 8,976 & 8,858 & 8,661 & 91.0 \\
$\begin{array}{l}\text { Novilk production, thous. tons } \\
\text { Milk }\end{array}$ & 227 & 221 & 220 & 217 & 199 & 70.6 \\
$\begin{array}{l}\text { Russian Federation } \\
\text { Novosibirsk region }\end{array}$ & 31,070 & 32,570 & 31,847 & 31,646 & 31,756 & 30,529 & 98.3 \\
\hline
\end{tabular}

In accordance with the currently implemented "Development of agriculture and regulation of markets for agricultural products, raw materials and food for years 2013-2020" state program, the share of milk and dairy products from domestic agricultural producers should be $90.2 \%$ by 2020 . However, currently the majority of agricultural organizations of Siberia cannot ensure large scale reproduction capable of providing access to target indicators all on their own. At the same time, the maintaining competitiveness of enterprises in this climatic zones, especially of large organizations, is necessary for providing food products of own mass production for population, and state support should compensate for inevitably increased costs in the industry due to unfavorable climatic conditions in the region and underdeveloped market. Most agricultural organizations in Siberia operate in extreme conditions and require a completely different approach to development (Gabdrakhmanov, Shelkovnikov, Ovsyanko, \& Kholodov, 2012; Matveev, Stadnik, \& Stadnik, 2011).

In order to assess economic efficiency of producing certain types of agricultural products by enterprises, and to determine target values of state support, we propose to use such indicators as:

- Profitability of sales of gross agricultural products $\left(P S_{g a p}\right)$;

- Influence of the state support for agricultural production on profitability level ( $\left.P P_{a c p}^{S S}\right)$;

- Comprehensive indicator of defining efficiency of production in agricultural organizations $\left(P_{G P}\right)$;

- Profitability of gross agricultural production based on state support $\left(P_{G P}^{S S}\right)$;

- Effectiveness of state support $\left(E_{S S}\right)$.

The indicator of profitability of agricultural gross sales $\left(P S_{\text {gap }}\right)$ describes how mush funds are allocated for the organization per ruble of profit from the selling agricultural products, taking into account cost of producing of the whole gross product that it can use for repaying its responsibilities and for reproduction:

$$
S P_{\text {gap }}=\frac{\sum\left(G_{i}-C_{i}\right)}{\sum G_{i}} \bullet 100
$$

where $\mathrm{i}$ is the kind of agricultural products;

I is the set of kinds of agricultural products;

$B i$ is the profit from sales of the $i$-th agricultural product, $i \in I$;

$C i$ is cost of production of the $i$-th gross agricultural product, $i \in I$.

The difference between the sales proceeds and the cost of production of gross agricultural product is the realizable income from production of the i-th gross agricultural product or its variety. 
The influence of the state support for agricultural production on profitability level can be assessed by the following formula:

$$
R S_{\text {gap }}^{S S}=\frac{\sum\left(G_{i}+S S_{i}-C_{i}\right)}{\sum G_{i}} \bullet 100
$$

where $R S_{a p}^{S S}$ is the return on sales from gross agricultural product with due regard to state support;

$S S i$ is the state support for agricultural production from the budgets of all levels, attributable to the financial result.

The comprehensive indicator of defining the efficiency of production in agricultural organizations - return on investment in gross agricultural production $\left(P_{G P}\right)$ is calculated by the following formula:

$$
P_{G P}=\frac{\sum\left(G_{i}-C_{i}\right)}{\sum C_{i}} \bullet 100 .
$$

Thus, using this indicator, one can assess the efficiency of producing a particular type of agricultural products, group, industry, or in the whole for the organization. The profitability of gross agricultural production with due regards to state support $\left(P_{G P}^{S S}\right)$ can be calculated by the following formula:

$$
P_{G P}^{S S}=\frac{\sum\left(G_{i}+G P_{i}-C_{i}\right)}{C_{i}} \bullet 100 .
$$

Then the efficiency of the state support for agricultural production will lie in the rate of increasing the actual level of profitability of the gross agricultural production with due regards to state support to its target values:

$$
E_{S S}=\frac{P_{G P}^{S S}-P_{G P}}{P_{G P}^{t a r}-P_{G P}} \bullet 100 \geq 100 \% .
$$

Calculation of the proposed indicators is shown in Table 2.

Table 2. Results of the agricultural production and its budget support in the agricultural organizations of the Novosibirsk Region*

\begin{tabular}{llllll}
\hline Indicators & 2008 & 2009 & 2010 & 2011 & 2012 \\
\hline Revenue from product sales, million rubles & 14,998 & 19,890 & 20,716 & 25,156 & 26,445 \\
costs associated with primary production, million rubles & 17,389 & 22,307 & 24,854 & 25,492 & 30,056 \\
$\begin{array}{l}\text { State support for agricultural production from the budgets of all } \\
\text { levels, classified as financial result }\end{array}$ & 1,051 & 1,831 & 1,464 & 1,381 & 1,711 \\
Level of profitability, \% & 11.4 & 12.4 & 4.6 & 7.6 & 9.1 \\
The level of profitability with due regard to state support, \% & 19.1 & 22.9 & 12.7 & 14.0 & 16.8 \\
Profitability of sales of agricultural products, \% & -15.9 & -12.2 & -20.0 & -1.3 & -13.7 \\
$\begin{array}{l}\text { Profitability of sales of agricultural products with due regard to } \\
\text { state support, \% }\end{array}$ & -8.9 & -2.9 & -12.9 & 4.2 & -7.2 \\
$\begin{array}{l}\text { Profitability of gross agricultural production, \% } \\
\text { Profitability of gross agricultural production with due regard to } \\
\text { state support, \% }\end{array}$ & -13.8 & -10.8 & -16.6 & -1.3 & -12.0 \\
Efficiency of state support for agricultural production, \% & -2.6 & -10.8 & 4.1 & -6.3 \\
\hline
\end{tabular}

* Compiled by the author basing on the financial statements of agricultural organizations in the Novosibirsk Region for 2008-2012. 
With the level of profitability at $16.8 \%$, the profitability of gross agricultural production in the agricultural organizations in the Novosibirsk region in 2012 was minus $12.0 \%$, and with the state support - minus $6.3 \%$. Similar situation exists in other regions of Siberia and the Far East: in Krasnoyarsk (respectively 18.1; -15.0 and 3.6) and the Altai (16.9; 5.7 and 3.6) provinces, Omsk (5.9; -13.1 and -8.9), Tomsk (21.2; -3.4 and 11.4), Amur (24.8; -6.9 and 7.6), Irkutsk (18, 6; -15.9 and -6.7), Kemerovo (10.7; -15.4 and -10.2) regions, Republics of Khakassia (5.4; 24.5 and -7.3) and Altai (23.2; -29.7 and -20.1).

The program of agriculture development and regulation of markets for agricultural products, raw materials and food stuffs for 2013-2020 includes the development of milk production as one of its priorities, using competitive advantages of regions. This should contribute to preservation of workforce in rural areas, ensuring economic and physical availability of foodstuffs on the basis of nutrition norms of food consumption for sensitive population, and increasing income of agricultural manufacturers in 2020.

However, the achievement of these goals is impossible without changing approaches to defining the scope and directions of the state support for the industry that are primarily focused on achieving specified profitability level of production and size of subsidies per $1 \mathrm{~kg}$ of milk sold.

For example, in the Novosibirsk region, the state support for agricultural organizations is used on the basis of gross milk yield, but its size varies considerably from year to year: from 25.4 million rubles in 2007 to 289.9 in 2012, which makes it impossible for producers to plan their long-term development programs. Thus, the profitability of milk sales in 2011 reached $46 \%$, but the profitability of its gross production with due regard to the state support accounted to only $13.6 \%$, i.e., even the simple cost recovery is not ensured.

Analytical grouping that reflects the influence of the state support on efficiency of milk production in agricultural organizations of the Novosibirsk region revealed that the highest level of profitability of gross milk production (39.7\%) is achieved in the group with the state support of about 6 million rubles per 1 farm, which ensures the best results with regard to performance indicators, too (Table 3).

Table 3. Relationship of state size and efficiency of milk production in agricultural organizations of the Novosibirsk Region, 2012

\begin{tabular}{|c|c|c|c|c|c|}
\hline \multirow[t]{2}{*}{ Indicators } & \multicolumn{5}{|c|}{$\begin{array}{l}\text { Groups of agricultural organizations by the level of state support for } \\
\text { milk production, million rubles }\end{array}$} \\
\hline & 0 & $0-0.5$ & $0.5-1$ & $1-3$ & $>3$ \\
\hline Number of farms in the group & 82 & 106 & 34 & 36 & 23 \\
\hline $\begin{array}{l}\text { State support for milk received, average } \\
\text { per farm, thousand rubles }\end{array}$ & 0 & 213.4 & 681.2 & 1719.0 & 6009.0 \\
\hline $\begin{array}{l}\text { Livestock of dairy herds in an average } \\
\text { household, animals }\end{array}$ & 470 & 369 & 531 & 560 & 764 \\
\hline $\begin{array}{l}\text { Production costs, average per } 1 \text { cow, } \\
\text { thousand rubles }\end{array}$ & 33.9 & 31.7 & 34.4 & 39.9 & 47.0 \\
\hline Level of merchantability, $\%$ & 82.7 & 85.1 & 87.6 & 88.4 & 92.3 \\
\hline Average annual yield per cow, $\mathrm{kg}$ & 2945.9 & 3114.1 & 3384.4 & 3684.4 & 4342.7 \\
\hline Level of milk sales profitability, $\%$ & 33.5 & 38.9 & 39.5 & 40.2 & 42.2 \\
\hline $\begin{array}{l}\text { Level of milk sales profitability with due } \\
\text { regard to state support, } \%\end{array}$ & 33.5 & 43.9 & 48.1 & 53.6 & 65.6 \\
\hline Profitability of gross milk production, $\%$ & 0.03 & 8.4 & 12.0 & 15.6 & 20.5 \\
\hline $\begin{array}{l}\text { Profitability of gross milk production with } \\
\text { due regard to state support, } \%\end{array}$ & 0.03 & 11.9 & 18.9 & 26.7 & 39.7 \\
\hline
\end{tabular}

It should be noted that $29.3 \%$ of the agricultural enterprises with dairy farming industry did not receive any state support for milk production in 2012. Only 32 agricultural organizations (11\% of their total number) managed to independently, without any state support, exceed the profitability level of milk production by $40 \%$, and 14 farms (5\%) - by 60\% (Gabdrakhmanov, 2012; Matveev, Stadnik, \& Menyaykin, 2014).

Study of the experience of leading agricultural companies made it possible to find target values of gross output profitability that ensure its expanded reproduction at index value of $40-60 \%$ or more. 
We have developed a method for determining the need for state support for agricultural production intended for ensuring its expanded reproduction on the basis of the indicator of profitability of gross agricultural production for each agricultural organization, municipal area, natural and economic zone and the region as a whole.

Then the target amount of the state support for gross milk production $\left(S P_{\text {milk }}^{\text {tar }}\right.$ ) is calculated by the following formula

$$
S S_{m i l k}^{\text {tar }}=\left(C_{G M P} \bullet P_{G M P}^{\text {tar }} / 100+1\right)-B_{S M}^{a c t},
$$

where $C_{G M P}$ is the cost of gross milk production;

$P_{G M P}^{t a r}$ - target yield of gross milk production;

$P_{M S}^{a c t}$ - actual profit from milk sale.

The required amount of state support per $1 \mathrm{~kg}$ of milk sold:

$$
S S_{1 k g}^{t a r}=S S_{m i l k}^{\text {tar }} / P M,
$$

where $P M$ is the amount of milk sales, $\mathrm{kg}$.

This method is simple and easy to use, and can be used to calculate necessary amount of support both at the level of a single product and at the level of their group, industry, agricultural manufacturer, district, region, and the country as a whole.

The proposed approach to defining target amounts of government support will contribute to adequation of business environment, since it takes into account the cost of products manufactured by agricultural enterprises that are initially in unequal economic conditions caused by climatic conditions, remoteness from markets, etc., and will make it possible for government bodies to understand the needs for support for agricultural organizations and to choose the direction and support mechanisms that ensure expanded reproduction.

Table 4. Forecast of milk production by agricultural organizations of the Novosibirsk region with various levels of government support

\begin{tabular}{lllllll}
\hline \multirow{2}{*}{ Year } & \multicolumn{2}{l}{ State support, million rubles } & \multicolumn{2}{l}{ Milk production, thousand tons } & \multicolumn{2}{l}{ Yield per cow, kg } \\
& $1^{*}$ & $2^{* *}$ & 1 & 2 & 1 & 2 \\
\hline 2015 & 175 & 1,009 & 471 & 796 & 4,155 & 5,905 \\
2016 & 177 & 1,017 & 469 & 800 & 4,282 & 5,931 \\
2017 & 179 & 1,026 & 467 & 803 & 4,410 & 5,958 \\
2018 & 182 & 1,035 & 465 & 807 & 4,537 & 5,984 \\
2019 & 184 & 1,044 & 463 & 811 & 4,665 & 6,010 \\
2020 & 187 & 1,052 & 461 & 814 & 4,792 & 6,036 \\
\hline
\end{tabular}

* Inertial variant; ** Ensuring expanded reproduction.

In view of the proposed model (6), and the use of correlation-regression analysis, we predicted the need for state support for gross milk production in the whole of the Novosibirsk region till 2020. At the same time, two variants have been developed with due regards to various levels of support: $1^{\text {st }}$ - inertial, based on existing industry trends and the level of its support; $2^{\text {nd }}$ - providing expanded reproduction and making it possible by 2020 , with budget costs of 1,052 million rubles, to manufacture 0.8 million tons of milk and reach $6,036 \mathrm{~kg}$ yield per cow (Table 4).

\section{Discussion}

One of the main tasks in state regulation of agriculture today becomes the support for competitiveness of domestic agricultural producers, especially in Siberia, due to adverse climatic conditions of the region, and undeveloped market, by compensating for inevitably increased costs of agricultural production to the level of expanded reproduction, using another system of parameters. The recommended indicator, return on sales of gross agricultural product without and with regard to the state support, describes how much profit comes from sales of agricultural products and funds received as support, per ruble of cost for production of all gross production. The 
comprehensive indicator used to define the efficiency of agricultural organizations, profitability of gross agricultural production, makes it possible to assess economic efficiency of producing an individual type of agricultural products, group, industry, or in the whole for the organization, both with and without government support.

\section{Conclusions}

1) Calculation of the efficiency of the state support for agricultural production as a growth in the rate of profitability of gross agricultural production due to the state support obtained before its target values, makes it possible to determine its role in refunding costs of agricultural organizations, or the extent to which the amount of support made it possible to reach the level of profitability of the gross agricultural production as a percent of target level.

2) The level of profitability of milk sales by agricultural organizations in 2012 was $46 \%$, but profitability of its gross production with regard to state support was only $13.6 \%$, which indicates the absence even of simple cost refunding in the industry. According to the grouping, $29.3 \%$ of the agricultural enterprises with dairy farming industry did not receive any state support for milk production in 2012. Only 32 agricultural organizations (11\% of the total number) managed to independently, without state support, exceed the profitability level of milk production by $40 \%$, and 14 farms (5\%) - by $60 \%$.

3) The developed method for determining the need for state support for agricultural production intended for ensuring its expanded reproduction on the basis of the indicator of profitability of gross agricultural production for each agricultural organization, municipal area, natural and economic zone and the region as a whole will make it possible for government bodies to understand the needs for support for agricultural organizations and to choose the direction and support mechanisms that ensure expanded reproduction.

\section{References}

Budanov, I. A. (2013). Resources and Conditions of Infrastructure Development in the Russian Federation. Studies on Russian Economic Development, 24(5), 422-432. http://dx.doi.org/10.1134/S1075700713050043

Cungu, A., Gow, H., Swinnen, J. F. M., \& Vranken, L. (2008). Investment with weak contract enforcement: Evidence from Hungary during Transition. European Review of Agricultural Economics, 35(1), 75. http://dx.doi.org/10.1093/erae/jbn001

Gabdrakhmanov, M. M., Shelkovnikov, S. A., Ovsyanko, L. A., \& Kholodov, P. P. (2012). State support as a Necessary Condition for Development of Dairy Cattle Breeding. AIC: Economics, Management, 9, 52-54.

Kovalev, L. I., \& Kovalev, I. L. (2013). Some Problems of Maintenance and Repair of Animal Husbandry. Russian Journal of Agricultural and Socio-Economic Sciences, 3, 22-25.

Malyshkov, V. I. (2013). Some Aspects of the Effective Relations between Government and Business. Life Science Journal, 10(4), 2679-2682.

Matveev, D. M., Stadnik, A. T., \& Menyaykin, D. V. (2014). Boosting the Investment Attractiveness of Agricultural Production. World Applied Sciences Journal, 31(8), 1535-1539.

Matveev, D. M., Stadnik, A. T., \& Stadnik, T. A. (2011). Process Control in Agricultural Organizations (p. 245). Novosibirsk: EKOR-kniga.

Official website of the Federal State Statistics Service. Retrieved December 4, 2014, from http://www.gks.ru/

Polukhin, A. A. (2014). Approaches for Justification Strategy Technical Modernization of Agriculture Given the Characteristics of Agricultural Development and Resource Provision Subjects of the Federation. Russian Journal of Agricultural and Socio-Economic Sciences, 24(12), 22-27.

Von Witzke, H. (2008). The World Food Economy. European Review of Agricultural Economics, 35(1), 114. http://dx.doi.org/10.1093/erae/jbn005

\section{Copyrights}

Copyright for this article is retained by the author(s), with first publication rights granted to the journal.

This is an open-access article distributed under the terms and conditions of the Creative Commons Attribution license (http://creativecommons.org/licenses/by/3.0/). 